\title{
THE BUDGET SYSTEM AND INTER-BUDGET TRANSFERS IN UKRAINE
}

\author{
OKSANA CHEBERYAKO
}

https://doi.org/10.35945/gb.2017.03.009

Doctor of Historical Science,

Ph.D. in Economics, Professor Taras Shevchenko National University of Kyiv, Ukraine

\author{
KEYWORDS: BUDGET STRUCTURE, BUDGET SYSTEM, LOCAL BUDGETS, \\ BUDGET UNITARIANISM, INTER-BUDGET TRANSFERS
}

The urgency of the research is predetermined that the budgetary system of any country is the main element of the financial system while the processes of unitarization and balance of local budgets takes place nowadays in the global stage. Measurements and characteristics of the budget system depend on the political structure of the state - unitary or federal. The budget system of Ukraine is determined by the state structure and the administrative territorial division of Ukraine.

Budget structure - includes organization and principles of the budget system and also the relationship between the links.

Ukraine, according to the article 2 of the Constitutions, is the unitary state, the typical features of which are integrity, indivisibility, absence in the composition of other state formations, functioning of unified system of law [2].

According to a unitary system in Ukraine consists annual state budget unitary type and the form of inter budgetary relations is based on the principles set out by the central government and its legislative acts. That budget system, which operates in Ukraine, is derived from the Constitution assigned the organization of state power.

In the unitary countries, which include Ukraine, budget system unites into two links: budget of central government and local budgets otherwise in the federal states there is the third link: members of federation's budget.

A term "budgetary system of Ukraine" found it in the Constitution of Ukraine of 1996. According to Article 2 of the Budget Code of Ukraine (BCU) the budgetary system of Ukraine is a set of the state budget and local budgets, built on the basis of economic relations, state and administrative-territorial system and regulated by the law. [3] (Fig. 1)

The budget system under Art. 95 of the Constitution of Ukraine is based on the principles of fair and impartial distribution of social wealth among citizens and territorial communities [2]. Citizens have equal rights to state budget revenues as taxes are paid "by the same rules of the game".

Composition of the budgetary system of Ukraine, its levels are defined on three criteria: 1 ) economic relations; 2) political system; 3) administrative-territorial division. These criteria are a reflection of Constitutions of Ukraine's norm (art 132, 133), that regulate the principles of the territorial and administrative-territorial structure of Ukraine [2].

Local budgets are the most numerous link of the budgetary system in Ukraine. All by the state to 01.12.2010 in Ukraine it is counted 12,052 independent local budgets which is divided as: Budget ARC (annexed by the Russian Federation) - 1; regional budgets - 24; municipal budgets of cities of Kyiv and Sevastopol - 2; district budgets - 496; budgets of local self-government - about 12,000, including: budgets of territorial communities of cities, cities of district value - 268, budgets of territorial communities of settlements - 804, budgets of territorial communities of villages - 10,187.

Ukraine is a second country after France by the number of local budgets among European countries, where there are 36,118 local budgets, including 22 regional budgets, budgets of 96 departments, 36,000 communes budgets.

The combination of all budgets that are a part of state and local budgets, is the erected (or consolidated) budget of Ukraine. The consolidated budget of Ukraine is used in the process of budget planning and budget management, and also for an analysis and prognostics of economic and social development.

The state structure is a determining factor of the formation of the budget system. In Ukraine, the preference was given to unitary state and due to this it is a logical combina-

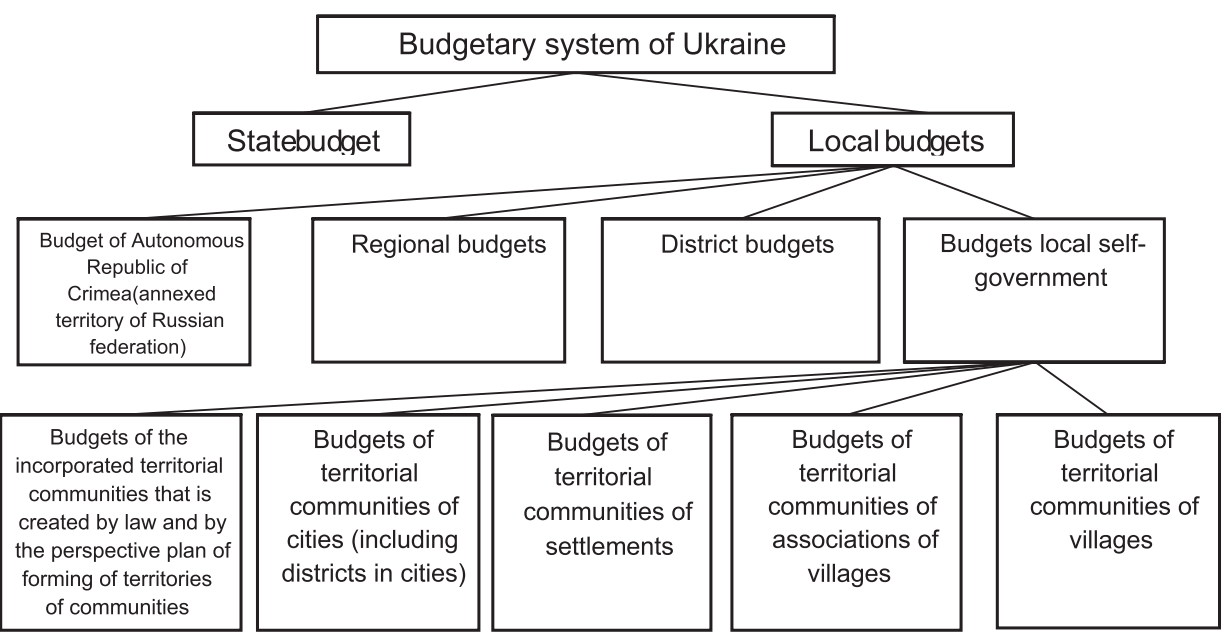

Fig. 1. Budgetary system of Ukraine 
tion of unitary government with a unitary, not federal budget system. Although the budgetary system of unitary type is created in Ukraine, the specific feature of its construction is independent of all budgets.

A significant place in the budget system belongs to the local budgets which were formed together with the creation of local self-government institution. On their maintenance, structure affects not only the political system but also the national features and organization of local government. According to Art. 140 of the Constitution of Ukraine, local self-government is a right for territorial society-habitants of village or voluntarily association in a rural community of habitants of a few villages, settlement and city - independently to decide the question of local value with in the limits of Constitution and laws of Ukraine[2].

The institute of local self-government began to be formed in Ukraine with a declaration of independence of the state, at the same time a right on existence of this institute is envisaged in European Charter of local self-government, which Ukraine joined in November in 1996 [1]. The formation of the local government in Ukraine election indicates the course of the process of decentralization of financial relations.

Determination of territorial society is given in the article. 1 of the Law of Ukraine " About local self-government ", 1997, which is initiated a new approach in relation with a determination of the concept of local budgets and their composition. The territorial community - residents, combined permanent residence within the village, the town, which is independent of the administrative-territorial units, or a voluntary association of several villages with a single administrative center. Territorial society is the habitants, incorporated by a permanent residence within the limits of village, settlement, city that is independent administrative-territorial units, or voluntarily association of habitants of a few villages that have a single administrative center [4]

According to art. 2 Budget Code of Ukraine a local budget is a plan of formation and use of financial resources for providing tasks and functions which carry out the government of Autonomous Republic of Crimea (annexed territory of Russian federation) and organs of local self-government during a budgetary period. Art. 5 determine local budgets, which include the budget of the Autonomous Republic of Crimea, regional budgets, district budgets, budgets of local self-government. In the unitary countries, the concept of local budgets coincides with the concept of local budgets. As Ukraine is the unitary state, that is why here it follows to consider the budgets of organs of local self-government (budgets of territorial communities of villages, their associations, settlements, cities (including districts in cities), budgets of the incorporated territorial communities that is created by law and by the perspective plan of forming of territories of communities).
The system of local budgets - a collection of independent local budgets, which are not included in the state budget and to each other.

Independence of local budgets is guaranteed by own and envisaged after them on stable basis by national profits, and also by rights independently to determine directions of the use of money of local budgets. Separately allocate revenues which are necessary for the performance of their own and delegated powers.

Minimum local budgets are based on the standards of budgetary material well-being per habitant or consumer of social services, taking into account economic, social, natural state of the areas, given the level of minimum social necessities set by a legislation.

In Ukraine legally proclaimed the principle of independence of local budgets, the amount of which is provided by the following sources of profits: own, fixed revenues and inter-budget transfers.

Own revenues are monetary resources that fully belong to the local budgets, and in the firmly fixed size set off to them, not arriving to the budgets of higher level and not included in the calculation of inter-budget transfers.

Fixed revenues are revenues which, in accordance with applicable law, belong to the state budget revenues and to balance local budgets are fixed in whole or in part (in \%) for the budgets of lower level indefinitely or on a long-term basis for their inclusion does not require a decision of the authorities higher advice (art. 143 Constitution of Ukraine sets that own revenues are as and districts do not have, but only fixed or attracted, if the general program is financed) [2].

Inter-budget transfers is money that is gratuitously and beyond retrieve passed from one budget to other. The main forms of inter-budget transfers according to BCU since 01.01.2015 are:

1) basic grants (transfer provided from the state budget to local budgets for horizontal fiscal equalization of territories);

2) subvention - interbudgetary transfers for the purposeful use in the order set by the body which made a decision on granting subvention.

3) reverse subsidy (funds transferred to the state budget of local budgets for horizontal fiscal equalization of territories);

4) additional subsidies (to compensate losses of local budgets that are not considered when determining the amount of interbudgetary transfers, resulting privileges established by the state).

Transfers (from the Latin. transferre - carry, transfer) characterize the process of transmission of property values between economic subjects on irreversible and no cost basis it takes place after that.

Budget transfers - funds which are transferred from the state budget to local budgets or local budgets higher level 
budgets to lower (and vice versa) in the form of grants, subsidies, subventions, etc. Transfers are important in moving funds from one level of government to another and is an integral part of all of interbudgetary relations in a unitary state and, above all, the relationship of the state budget with the budgets of local governments. If the transfer is carried out between the different levels, there is a vertical movement of funds. Transfers between the budgets of other levels cause the horizontal movement of funds. But transfers are not limited to cash flow, as is generally typical of financial relations, they may include the transfer of property in kind. The volume of transfers is determined by the difference between the expenditures of local budgets and their own and fixed revenues.

Inter-budget transfers are classified due to the different criteria. By way of the transfer of funds to the budget are direct transfers (a direct transfer of funds) or indirect (transfer of territorial authorities the right to income from certain national tax payments or shares them within the tax splitting). At the legislative level and in the research usually the term is used to direct transfers or as they are still called, official transfers.

Depending on the targeted use all official budget transfers scholars usually divides into two groups:

- current, which include cash assistance (grants) budget lower than the shortage of revenue sources, and the aim of current transfers is an a balance of these budgets;

- capital (grants), providing targeted use of funds received and therefore directly affect the structure of expenditures, which they receive; the purposes for which are allocated subventions, related mainly to implementation of local self-government of the plenary powers delegated the state organs head for.

According to the $\mathrm{BCU}$, transfers are divided into three groups. The first group includes transfers which are carried out in order of smoothing of budgetary possibility on a free and irrevocable basis to cover operating costs: 1) basic grant (it was called a grant alignment) - is given from the state budget for fiscal horizontal equalization territories; 2) transfers to the state budget of Ukraine and local budgets from other local budgets - reverse subsidy (funds are transferred to the state budget of local budgets for horizontal fiscal equalization of territories). The second group includes transfers which are provided for a particular purpose and in order to be set by the body, which made a decision on granting subvention: subventions for the implementation of public social protection programs; additional subsidy to compensate losses of local budgets due to privileges established by the state; subvention for investment projects; educational subventions - to pay for current expenditures of secondary schools of all types; subventions for training of working personnels - to pay for current expenditures of vocational education institutions; medical subventions - on maintenance of institutions and establishments of health protection; subvention for financ- ing of socio-economic compensation for the risk population, living in the area of supervision zone; subvention for projects liquidation of coal and peat industry and the maintenance of pumping complexes in the safe mode in co-financing (50 percent). The third group includes other unconditional transfers which are provided free of charge and irrevocable basis in the form of subsidies (stabilization subsidy - it is envisaged in the state budget for coverage of actual disproportions at the input of new model of mutual relations of the state budget with local budgets) $[3,6]$.

Procedures of distribution and use of subsidies and grants are defined by the Cabinet of Ministers of Ukraine. An updated version BCU determines that expenditures on medical institutions, secondary schools and institutions, which provide training to workers, carried out at the expense of local budgets and subsidies from the state budget. So now due to the budgetary institutions which receive subsidies, are allowed to make expenditures for financing in conjunction with a state and local budgets and / or from the different budgets during this period. Thus, all medical and educational institutions regardless of the region will be in a level playing field. At the same time a part of subsidy is necessarily expected to the reserve funds, the amount of which cannot exceed $1 \%$ of the total subsidy for expenditure that could not be taken into account when applying the formula that determines the allocation subvention between local budgets.

Basic grant to the budgets of cities of district, budgets of town and village will be given only in case of their association and creation of the incorporated territorial communities (ITC) [5].The budgets of ITC have the inter budgetary relations with the state budget, namely inter-budget transfers are approved by the law of the state budget annually. There is a basic grant, educational subventions, medical subventions and other grants and subventions, if there are grounds for giving and receiving relevance in the inter-budget transfers (art. 97, 99, 100, 102, 103-2, 103-4 and 108 BCU).

All in all, such tasks are decided by supporting of budget transfers:

- achieve a balanced budget, and make an active influence on the structure of expenditures of local budgets;

- provide a grant alignment of the budgetary disproportions in a context of country's territories;

- the socio-economic programs of national value are funded;

- improve the quality of service to consumers and their proper financial support by introducing basic grants (reverse subsidy), educational subventions, subventions for training of workers, medical subventions, subventions for providing medical facilities of individual state programs. The comprehensive measures of programmatic nature indicates that the state by transferring specific transfers (subsidies) fully takes responsibility in relation with the financial current adjust- 
ment of medical as well as educational spheres that belong to plenary powers of local budgets and fold a considerable volume in their charges.

- introduce the special subventions which contribute to the flexibility in management of budgetary facilities within the limits of general balance of resources of the state;

- ensure the development of the local economy in accordance with the certain national priorities.

In terms of budget system of unitary type are used the various instruments of financial support to local budgets, but the most common are the transfers, which are an important part of the financial relations of society. In general, the budget should be sufficient to delegated and own powers, and to provide public social services is not below the minimum social guarantees.

In foreign countries an extensive system of transfer is formed, which includes general or universal transfers, with leveling function, and also targeted and specific which are allocated to the specific needs. The common transfer system is used for horizontal alignment of budgetary imbalances. But through the system of general transfers are resolved care "problem" territories. Those practices are particular, for example, in Germany, which uses a method of creating a separate common fund transfers ("additional federal payments") to provide financial assistance to the Eastern states. The level of development and the state budget do not allow at once plugging them in the general system of the budgetary hori- zontal grant alignment, that functions are on the basis of general transfers for all regions in Germany.

Through transfers in many countries are formed the dominant part of revenues of local governments (in Malta $-98 \%$ of revenues of municipal budgets, Romania - 79\%, Latvia - $68 \%$, Slovenia - $67 \%$, in the UK - $77 \%$, in the Netherlands - $60 \%$ ). In some countries, local governments in the formation of their current revenues are critically dependent on transfers from the central budget - Italy, Ireland, Canada, Portugal. Their transfers make up 60 to $80 \%$ of current revenues. Transfer funding of local budgets by central administration indicates an intense redistribution of national revenues through budgetary channels with the aim of removal of disproportions in the development of territories.

Namely for the local budgets, as to the main financial basis of local self-government, the special place belongs to the budgetary system of our state. Over $80 \%$ of financial resources are concentrated in the organs of local self-government. However, the system of local budgets in Ukraine is characterized by weakness and chronic deficits, due to the fact that transferred to local authorities functions cannot independently implement owing to the lack of financial base. Every year a share of local budgets is declined in the structure of the consolidated budget of Ukraine in accordance with the share of state budget revenues growing. This shows that local governments are not financially self-sufficient, so a fiscal decentralization takes place in Ukraine.

\section{REFERENCES:}

1. European Charter of Local Self-Government from 15.10.1985p. [Electronic resource] // Parliament of Ukraine [site]. - Access: http://zakon0.rada.gov.ua/laws/show/994_036.

2. The Constitution of Ukraine number 254k / 96-VR from 28.06.1996. - Access: zakon.rada.gov.ua/go/254к/96-вр.

3. Budget Code of Ukraine № 2456-VI from 08.07.2010. .- Access: http://zakon3.rada.gov.ua/laws/show/2456-17.

4. The Law of Ukraine «On Local Government» № 280/97-VR from 27.05.1997. .- Access: zakon.rada.gov.ua/laws/ show/280/97-вp.

5. The Law of Ukraine «On a voluntary association of local communities» № 676-VIII from 04.09.2015. .- Access: zakon.rada. gov.ua/laws/show/157-19.

6. Law of Ukraine «On Amendments to the Budget Code of Ukraine on the reform of interbudgetary relations» № 79-VIII. from 28/12/2014.- Access: http://zakon4.rada.gov.ua/laws/show/79-19.

7. Resolution of Cabinet of Ministers of Ukraine «On Approval of Procedures capable of forming local communities» №214 of 04/08/2015. - Access: http://zakon0.rada.gov.ua/laws/show/214-2015-п.

8. Cheberyako O.V. Inter budgetary relations in Ukraine unitary state. - K .:Worldview, 2004. - 190p. 


\section{THE BUDGET SYSTEM AND INTER-BUDGET TRANSFERS IN UKRAINE}

OKSANA CHEBERYAKO

https://doi.org/10.35945/gb.2017.03.009

Doctor of Historical Science,

Ph.D. in Economics, Professor Taras Shevchenko National University of Kyiv, Ukraine

KEYWORDS: BUDGET STRUCTURE, BUDGET SYSTEM, LOCAL BUDGETS, BUDGET UNITARIANISM, INTER-BUDGET TRANSFERS

\section{SUMMARY}

The budget system is the leading element of public finances and the structure of state is a determining factor in the formation of the budget system. In the unitary countries, which include Ukraine, the budget system unites two links: budget of central government and local budgets, otherwise in the federal states there is the third link: members of federation's budgets. Local governments are the largest element of the budget system in Ukraine (totally there were 12,052 independent local budgets to 01.12.2010), but now their number is reduced in the connection with the financial decentralization and the creation of integrated communities. Local governments are independent, and the main sources of revenues are own, fixed revenues and inter-budget transfers. The main forms of inter-budget transfers contain the basic subsidy, subvention, reversible subsidy, additional subsidies. Transfers are the most common tools of financial support to local budgets; that the volume of local budget revenues was sufficient to delegated and own powers, and to provide public services is not below the minimum of social guarantees. 